\title{
Global and National Socioeconomic Disparities in Obesity, Overweight, and Underweight Status
}

\author{
Spencer Moore, ${ }^{1,2}$ Justin N. Hall, ${ }^{1}$ Sam Harper, ${ }^{3}$ and John W. Lynch ${ }^{3,4,5}$ \\ ${ }^{1}$ School of Kinesiology and Health Studies, Queen's University, 28 Division Street Room 310-F, Kingston, ON, Canada K7L $3 N 6$ \\ ${ }^{2}$ Centre de Recherche du Centre Hospitalier de l'Université de Montréal, Montréal, QC, Canada H2W 1 V1 \\ ${ }^{3}$ Department of Epidemiology, Biostatistics, and Occupational Health, Faculty of Medicine, McGill University, \\ Montréal, Canada H3A 1 A2 \\ ${ }^{4}$ School of Health Sciences, University of South Australia, SA 5001 Adelaide, Australia \\ ${ }^{5}$ Department of Social Medicine, University of Bristol, BS82PS Bristol, UK
}

Correspondence should be addressed to Spencer Moore, mooresp@queensu.ca

Received 11 December 2009; Accepted 1 February 2010

Academic Editor: Lawrence Cheskin

Copyright ( 2010 Spencer Moore et al. This is an open access article distributed under the Creative Commons Attribution License, which permits unrestricted use, distribution, and reproduction in any medium, provided the original work is properly cited.

\begin{abstract}
Objective. To examine the association between socioeconomic factors and weight status across 53 countries. Methods. Data are cross-sectional and from the long version of the World Health Survey (WHS). There were 172,625 WHS participants who provided self-reported height and weight measures and sociodemographic information. The International Classification of adult weight status was used to classify participants by body mass index (BMI): (1) underweight (<18.5), (2) normal weight (18.5-24.9), (3) overweight (25.0-29.9), and (4) obese (>30.0). Multinomial regression was used in the analyses. Results. Globally, 6.7\% was underweight, $25.7 \%$ overweight, and $8.9 \%$ obese. Underweight status was least (5.8\%) and obesity (9.3\%) most prevalent in the richest quintile. There was variability between countries, with a tendency for lower-income quintiles to be at increased risk for underweight and reduced risk for obesity. Conclusion. International policies may require flexibility in addressing cross-national differences in the socio-economic covariates of BMI status.
\end{abstract}

\section{Introduction}

Overweight and obesity have been defined as abnormal or excessive accumulations of fat in the body that may impair health [1]. Overweight and obesity results from an energy imbalance in the amount of calories consumed and the amount of calories expended [1]. The rise of overweight and obesity globally has been attributed primarily to a twofold process: (1) a global shift toward a diet richer in caloric sweeteners, animal source foods, and fats, and (2) decreased physical activity patterns due to changes in the nature of work, modes of transportation, and urbanization $[2,3]$. Overweight and obesity have been found to be major risk factors for chronic diseases, including cardiovascular disease, diabetes, musculoskeletal disorders, and some forms of cancer [1]. Although higher levels of overweight and obesity and, by extension, chronic diseases have generally characterized developed countries such as the United States, the rates of overweight and obesity are increasing much faster in the developing world $[4,5]$.

Undernutrition is due to food intake that is continuously insufficient or poorly absorbed and retained in the body to meet and maintain energy requirements [6]. Undernutrition is epidemic in parts of the developing world with its occurrence generally associated with high rates of infectious diseases [2] and has been estimated to contribute to the deaths of 5-6 million children under 5 each year [7]. Undernutrition affects all age groups and is especially common among the poor and those lacking clean water and good sanitation. Famines, civil conflicts and wars also contribute to undernutrition [8]. Although earlier research on global undernutrition often suggested that national economic development would lead progressively to lower levels of undernutrition within developing countries, more recent research has highlighted the cooccurrence of high levels of under- and overnutrition within countries $[4,9,10]$. 
Often referred to as the "double burden of malnutrition," [2] this paradoxical phenomenon places tremendous strains on the health systems of developing countries since national governments must confront the increased costs associated with nutrition-related chronic diseases as well as the continued need to address undernutrition and infectious disease $[11,12]$.

Assessment of the socio-economic disparities in underweight, overweight, and obesity status globally is important to addressing the problem of chronic disease [12]. Knowledge of the worldwide distribution of weight status and how weight status may vary by socio-economic factors can provide baseline information for monitoring global and national socio-economic disparities in weight status and assist policymakers in the allocation of resources [2]. Estimates of weight status may come from either direct or self-reported measures of height and weight. Direct measures of height and weight tend to provide more accurate prevalence estimates of body mass index (BMI) than selfreported measures since they reduce social desirability biases in reporting [13]. Nevertheless, self-reported height and weight measures remain as equally correlated with disease biomarkers as direct measures [14] and have been shown associated with mortality due to cardiovascular and coronary heart disease [15]. Self-reported height and weight data thus remain valid for identifying relationships in large epidemiological studies $[14,16]$. because they are lower in cost, less intrusive to collect [13]. The lower costs of self-reported studies of height and weight are particularly relevant for resource-poor countries where surveillance of infectious disease may have financial priority over the surveillance of population weight status.

Unique about the WHS is that the instruments to measure health outcomes and socio-economic indicators are directly comparable across countries. Using these data, this study provides the largest directly comparable cross-national report on the association between socio-economic factors and BMI status available and identifies on a country-bycountry basis, the role played by income, sex, and urbanicity in underweight, overweight, and obese status. Furthermore, given the WHS's focus on population health surveillance among low-income countries, this study reports data for many developing countries that have until now lacked published information.

\section{Methods}

2.1. WHS Population and Design. The long version of the World Health Survey (WHS), a large cross-sectional study, was administered in 51 countries in 2002-2003 to assess the global prevalence of behavioral risk factors, mental health, and chronic health conditions [17, 18]. The long version of the WHS was administered primarily in lowincome countries, although several high- and middleincome countries were also included. The WHS's sampling frame covered 100 percent of a country's eligible population. The target population included any male or female adult aged 18 or over, present in the country and residing in a private household during the survey period. The WHS was the first survey designed with explicit attention to crossnational comparability in instrument development [19]. Additional information about the WHS sample and survey methodology is available on the WHS website [17].

2.2. Self-Reported Height and Weight. Participants were asked to report their height in either meters and centimeters or feet and inches and their weight in either kilograms or pounds. Heights reported in feet and inches were converted to centimeters and weights reported in pounds were converted to kilos to calculate each person's body mass index (BMI). BMI was calculated as weight in kilograms divided by height in meters squared $\left(\mathrm{kg} / \mathrm{m}^{2}\right)$. BMI values are age-independent and applicable to both sexes [20, 21]. The International Classification of adult underweight, normal weight, overweight, and obesity was used to group individuals according to BMI: (1) underweight $(<18.5),(2)$ normal weight (18.5-24.9), (3) overweight (25.0-29.9), and (4) obese (>30.0) [20].

To reduce potential reporting biases, observations were dropped if their reported height was less than 122 centimeters $(n=1092)$ or greater than 211 centimeters $(n=56)$; observations were also dropped if their reported weight was 3 standard deviations above $(n=1359)$ or 1.5 standard deviations below $(n=7089)$ the crude sample mean of 63.1 kilograms. Application of these exclusion criteria was intended to eliminate the statistically outlying height and weight self reports and resulted in the exclusion of a study sample of respondents with self-reported BMI below 11.3 and above $63.2 \mathrm{~kg} / \mathrm{m}^{2}$.

2.3. Socio-Demographic Characteristics. Household permanent income was measured using the asset-based approach developed by Ferguson and colleagues [22], which has been used in previous cross-national studies of economic status and health in developing countries [23]. This approach assumes that economic status is an unobserved latent variable and is estimated by a random-effects probit model using measures of household ownership of assets (e.g., refrigerator, radio, car, etc.), access to services (e.g., drinking water), and known predictors of income (e.g., age and education). Coefficients on the asset variables from the model indicate thresholds on the latent income scale above which households are more likely to own particular assets; that is, if a household's estimated permanent income is greater than the asset threshold, there is a greater than. 5 probability that they own the item. This asset scale is then applied to each household to estimate permanent income. Previous research has shown these estimates of household income to provide valid and reliable, if imperfect, estimates of permanent income [24]. Estimates of household permanent income were categorized into quintiles within each country. The WHO provided the income information used in this study. National survey units provided definitions of what constituted urban areas and interviewers recorded urbanicity status at the time of the interview [17]. Countries 
TABLE 1: Characteristics of WHS body mass index (BMI) sample, by country and in total, WHS, 2002-2003.

\begin{tabular}{|c|c|c|c|c|c|c|c|c|}
\hline Country & $\begin{array}{c}\text { Initial } \\
\text { sample size }\end{array}$ & $\begin{array}{l}\text { Number } \\
\text { missing height } \\
\text { or weight } \\
\text { information }\end{array}$ & $\begin{array}{c}\text { Number } \\
\text { excluded based } \\
\text { on BMI }(<11.3 \\
\text { or } \\
\left.>61.2 \mathrm{~kg} / \mathrm{m}^{2}\right) \\
\end{array}$ & $\begin{array}{c}\text { Number } \\
\text { missing socio- } \\
\text { demographic } \\
\text { information }\end{array}$ & $\begin{array}{c}\text { Final sample } \\
\text { size }\end{array}$ & $\%$ males & $\begin{array}{l}\text { Mean } \\
\text { age }\end{array}$ & \% Urban \\
\hline Bangladesh & 5942 & 5071 & 61 & 7 & 803 & $86.1 \%$ & 35.3 & $52.6 \%$ \\
\hline Bosnia-Herzegovina & 1031 & 17 & 16 & 3 & 995 & $41.5 \%$ & 46.9 & $42.2 \%$ \\
\hline Brazil & 5000 & 587 & 108 & 158 & 4147 & $46.3 \%$ & 41.1 & $83.7 \%$ \\
\hline Burkina Faso & 4948 & 3215 & 23 & 40 & 1670 & $51.7 \%$ & 34.0 & $44.9 \%$ \\
\hline Chad & 4875 & 1393 & 126 & 184 & 3172 & $50.3 \%$ & 36.6 & $24.9 \%$ \\
\hline China & 3994 & 6 & 107 & 35 & 3846 & $50.1 \%$ & 44.7 & $39.8 \%$ \\
\hline Comoros & 1836 & 103 & 29 & 82 & 1622 & $45.5 \%$ & 42.0 & $29.7 \%$ \\
\hline Congo & 3077 & 863 & 68 & 85 & 2061 & $47.7 \%$ & 36.1 & $80.7 \%$ \\
\hline Côte d'Ivoire & 3251 & 381 & 75 & 144 & 2651 & $60.0 \%$ & 35.2 & $60.2 \%$ \\
\hline Croatia & 993 & 24 & 20 & 38 & 911 & $40.2 \%$ & 52.4 & $66.0 \%$ \\
\hline Czech Republic & 949 & 46 & 32 & 18 & 853 & $43.4 \%$ & 47.7 & $71.6 \%$ \\
\hline Dominican Republic & 5027 & 1907 & 93 & 47 & 2980 & $50.8 \%$ & 40.4 & $57.8 \%$ \\
\hline Ecuador & 5677 & 1569 & 216 & 396 & 3496 & $45.8 \%$ & 40.8 & $68.1 \%$ \\
\hline Estonia & 1021 & 23 & 32 & 11 & 955 & $35.3 \%$ & 49.6 & $66.2 \%$ \\
\hline Ethiopia & 5090 & 4119 & 16 & 36 & 919 & $71.9 \%$ & 31.6 & $26.6 \%$ \\
\hline Georgia & 2950 & 213 & 49 & 109 & 2579 & $42.3 \%$ & 48.5 & $43.9 \%$ \\
\hline Ghana & 4165 & 461 & 170 & 224 & 3310 & $46.2 \%$ & 40.5 & $38.3 \%$ \\
\hline Guatemala & 4890 & 1735 & 85 & 201 & 2869 & $46.8 \%$ & 39.2 & $44.4 \%$ \\
\hline Hungary & 1419 & 30 & 54 & 36 & 1299 & $40.5 \%$ & 49.4 & $61.0 \%$ \\
\hline India & 10692 & 1322 & 1771 & 293 & 7306 & $55.9 \%$ & 39.1 & $30.3 \%$ \\
\hline Kazakhstan & 4499 & 231 & 56 & 26 & 4186 & $34.9 \%$ & 41.5 & $58.6 \%$ \\
\hline Kenya & 4640 & 342 & 159 & 119 & 4020 & $43.6 \%$ & 37.3 & $31.6 \%$ \\
\hline Laos & 4989 & 109 & 528 & 816 & 3536 & $50.7 \%$ & 37.7 & $30.1 \%$ \\
\hline Latvia & 929 & 196 & 16 & 3 & 714 & $34.5 \%$ & 49.3 & $70.6 \%$ \\
\hline Malawi & 5551 & 309 & 173 & 214 & 4855 & $43.0 \%$ & 35.8 & $15.5 \%$ \\
\hline Malaysia & 6145 & 1136 & 253 & 210 & 4546 & $48.7 \%$ & 39.9 & $63.4 \%$ \\
\hline Mali & 5209 & 4791 & 19 & 73 & 326 & $88.0 \%$ & 39.4 & $40.5 \%$ \\
\hline Mauritania & 3907 & 643 & 238 & 440 & 2586 & $38.8 \%$ & 39.0 & $40.3 \%$ \\
\hline Mauritius & 3968 & 1387 & 118 & 40 & 2423 & $62.7 \%$ & 41.1 & $48.7 \%$ \\
\hline Mexico & 38746 & 15345 & 508 & 225 & 22668 & $42.5 \%$ & 41.2 & $71.3 \%$ \\
\hline Morocco & 5000 & 2961 & 36 & 281 & 1722 & $67.4 \%$ & 38.7 & $62.5 \%$ \\
\hline Myanmar & 6045 & 166 & 335 & 5 & 5539 & $45.4 \%$ & 40.8 & $24.6 \%$ \\
\hline Namibia & 4379 & 573 & 168 & 187 & 3451 & $40.8 \%$ & 37.8 & $48.1 \%$ \\
\hline Nepal & 8822 & 5629 & 328 & 257 & 2608 & $68.4 \%$ & 35.0 & $21.1 \%$ \\
\hline Pakistan & 6502 & 3050 & 310 & 307 & 2835 & $64.8 \%$ & 37.0 & $41.2 \%$ \\
\hline Paraguay & 5288 & 653 & 90 & 40 & 4505 & $49.1 \%$ & 39.8 & $47.8 \%$ \\
\hline Philippines & 10083 & 1896 & 591 & 39 & 7557 & $51.3 \%$ & 38.3 & $60.0 \%$ \\
\hline Russia & 4427 & 944 & 43 & 67 & 3373 & $35.7 \%$ & 49.0 & $92.5 \%$ \\
\hline Senegal & 3465 & 1794 & 55 & 345 & 1271 & $59.9 \%$ & 37.9 & $59.7 \%$ \\
\hline Slovakia & 2535 & 758 & 37 & 90 & 1650 & $33.3 \%$ & 37.3 & $90.8 \%$ \\
\hline Slovenia & 687 & 119 & 10 & 8 & 550 & $46.2 \%$ & 47.2 & - \\
\hline South Africa & 2629 & 1033 & 258 & 82 & 1256 & $51.4 \%$ & 37.3 & $62.3 \%$ \\
\hline Spain & 6373 & 257 & 71 & 81 & 5964 & $41.3 \%$ & 52.3 & $72.1 \%$ \\
\hline Sri Lanka & 6805 & 1066 & 962 & 116 & 4661 & $53.4 \%$ & 40.9 & $16.3 \%$ \\
\hline Swaziland & 3121 & 1269 & 141 & 130 & 1581 & $44.4 \%$ & 37.5 & $24.3 \%$ \\
\hline Tunisia & 5203 & 988 & 51 & 47 & 4117 & $50.9 \%$ & 40.6 & $65.3 \%$ \\
\hline
\end{tabular}


TABle 1: Continued.

\begin{tabular}{|c|c|c|c|c|c|c|c|c|}
\hline Country & $\begin{array}{c}\text { Initial } \\
\text { sample size }\end{array}$ & $\begin{array}{l}\text { Number } \\
\text { missing height } \\
\text { or weight } \\
\text { information }\end{array}$ & $\begin{array}{c}\text { Number } \\
\text { excluded based } \\
\text { on BMI }(<11.3 \\
\text { or } \\
\left.>61.2 \mathrm{~kg} / \mathrm{m}^{2}\right)\end{array}$ & $\begin{array}{c}\text { Number } \\
\text { missing socio- } \\
\text { demographic } \\
\text { information }\end{array}$ & $\begin{array}{c}\text { Final sample } \\
\text { size }\end{array}$ & $\%$ males & $\begin{array}{l}\text { Mean } \\
\text { age }\end{array}$ & $\%$ Urban \\
\hline Turkey & 11481 & 3314 & 124 & 2 & 8041 & $51.4 \%$ & 40.6 & $50.5 \%$ \\
\hline Ukraine & 2860 & 170 & 55 & 448 & 2187 & $36.2 \%$ & 47.0 & $78.0 \%$ \\
\hline United Arab Emirates & 1183 & 39 & 41 & 19 & 1084 & $52.0 \%$ & 37.2 & $76.8 \%$ \\
\hline Uruguay & 2996 & 46 & 70 & 33 & 2847 & $48.0 \%$ & 45.8 & $83.4 \%$ \\
\hline Vietnam & 4174 & 692 & 469 & 18 & 2995 & $50.8 \%$ & 39.4 & $22.9 \%$ \\
\hline Zambia & 4166 & 1922 & 61 & 44 & 2139 & $47.5 \%$ & 35.3 & $39.2 \%$ \\
\hline Zimbabwe & 4292 & 1755 & 71 & 78 & 2388 & $42.0 \%$ & 35.4 & $41.5 \%$ \\
\hline Total & 267926 & 78668 & 9596 & 7037 & 172625 & $49.4 \%$ & 40.8 & $51.6 \%$ \\
\hline
\end{tabular}

were grouped into world regions based on the WHO regional office divisions [25].

For this report, with certain exceptions, observations were excluded if they were missing data on sex, age, income, urbanicity, and sampling units. Analyses were adjusted for age, which was grouped into six categories: (1) 18-29 years old, (2) 30-39 years old, (3) 40-49 years old, (4) 50-59 years old, (5) 60-69 years old, and (6) 70 years plus. If the country as a whole was missing data on a particular variable, for example, income, analyses were conducted using the available variables. These instances were as follows: Turkey was missing income data; Slovenia was lacking urbanicity information; Guatemala and Slovenia were missing sampling information.

2.4. Analyses. Countrywide and sex-specific country prevalence estimates of weight status were calculated based on WHO World Standard age standardization estimates [26] and weighted according to the sampling design (based on selection probability, nonresponse, and poststratification) with the exception of Guatemala and Slovenia. Crude worldwide prevalence estimates of BMI status based on self-reported height and weight by income quintile were calculated. Crude prevalence rates of BMI status are reported for urban and rural residents according to the WHO region.

To examine patterns of BMI status according to sex, income, or urbanicity in the risk of being underweight, overweight, or obese, multivariable multinomial regression analyses with a robust error variance were conducted on a country-by-country basis. Normal BMI (18.5-24.9) was taken as the reference category. For countries with no missing data, relative risk ratios (RRRs) and 95\% confidence intervals (95\% CIs) were adjusted for sex, urbanicity, and household income. Countries are reported as indicating significant differences with $P<.05$ using clustered robust standard errors with clusters consisting of the country's primary sampling units (PSUs). PSU information was missing for Guatemala, Slovenia, and Zambia and, as a result, robust standard errors were used for these countries. Table 4 provides a summary report of the countries in which particular relationships were shown for each factor. Results of countryby-country analyses are available in Supplementary Material available online at doi: 10.1155/2010/514674. There were seven countries in which sparse data within certain categories of age and/or income required that the age or income variable take a modified form. This piece of information is reported in the footnotes of supplementary tables. Data were analyzed using Stata, version 10.

\section{Results}

3.1. Response Rates and Demographics. Sample characteristics are displayed in Table 1. Of the 267,926 WHS participants within the 53 countries in this study, 189,258 individuals reported information on their height and weight for an overall response percentage of $74.6 \%$ to height and weight items. An additional 9596 individuals were dropped from this study for not meeting height and weight inclusion criteria. In addition, 7037 observations were dropped for missing one or more observations on socio-demographic variables. In cases where the entire country did not provide information on a specific socio-demographic variable (e.g., Turkey and income) individuals were not dropped from the analysis. The study's final sample size was 172,625 observations, or $64.4 \%$ of the original sample. The final sample size of countries as a percentage of the original sample ranged from $6.3 \%$ (Mali) to $96.3 \%$ (China).

The overall percentage of males in the sample was $49.4 \%$ with a range of $33.3 \%$ (Slovakia) to $88.0 \%$ (Mali). Mean age was 40.8 years and ranged from 31.6 years (Ethiopia) to 52.4 years (Croatia). The overall percentage of urban-dwelling respondents was $51.6 \%$ with a range from $15.5 \%$ (Malawi) to $92.5 \%$ (Russian Federation).

3.2. Distribution of Weight Status by Sex, Income, and Urban/Rural Residence. Of the study's sample, $6.7 \%$ was classified as underweight, $25.7 \%$ as overweight, and $8.9 \%$ as obese.

3.2.1. Sex. Compared to women, the distribution of weight status for men leaned toward lower BMI categories. Men 
TABLe 2: Prevalence of body mass index (BMI) classification, by sex (male) and country, WHS, 2002-2003.

\begin{tabular}{|c|c|c|c|}
\hline Male & Underweight & Overweight & Obese \\
\hline Country & $\%$ (95\% Confidence Intervals) & $\%$ (95\% Confidence Intervals) & $\%$ (95\% Confidence Intervals) \\
\hline Bangladesh & $16.3 \%(11.4 \%-21.2 \%)$ & $10.4 \%(7.5 \%-13.4 \%)$ & $1.2 \%(0.5 \%-1.8 \%)$ \\
\hline Bosnia and Herzegovina & $3.0 \%(0.3 \%-5.7 \%)$ & $34.5 \%(28.8 \%-40.2 \%)$ & $3.9 \%(1.6 \%-6.1 \%)$ \\
\hline Brazil & $4.1 \%(2.7 \%-5.5 \%)$ & $29.9 \%(27.5 \%-32.3 \%)$ & $6.4 \%(5.3 \%-7.5 \%)$ \\
\hline Burkina Faso & $5.7 \%(2.9 \%-8.5 \%)$ & $11.3 \%(8.7 \%-13.8 \%)$ & $0.9 \%(0.2 \%-1.5 \%)$ \\
\hline Chad & $5.5 \%(3.8 \%-7.3 \%)$ & $25.9 \%(22.4 \%-29.4 \%)$ & $8.0 \%(5.8 \%-10.2 \%)$ \\
\hline China & $13.5 \%(8.9 \%-18.2 \%)$ & $12.5 \%(8.0 \%-17.0 \%)$ & $0.8 \%(0.3 \%-1.3 \%)$ \\
\hline Comoros & $6.0 \%(3.9 \%-8.1 \%)$ & $17.8 \%(14.8 \%-20.7 \%)$ & $1.6 \%(0.6 \%-2.7 \%)$ \\
\hline Congo & $3.9 \%(2.3 \%-5.5 \%)$ & $23.5 \%(17.8 \%-29.1 \%)$ & $2.6 \%(1.3 \%-3.8 \%)$ \\
\hline Côte d'Ivoire & $5.5 \%(2.9 \%-8.1 \%)$ & $18.5 \%(16.1 \%-20.9 \%)$ & $2.5 \%(1.5 \%-3.5 \%)$ \\
\hline Croatia & $0.6 \%(0.0 \%-1.4 \%)$ & $40.7 \%(34.6 \%-46.7 \%)$ & $11.1 \%(7.1 \%-15.1 \%)$ \\
\hline Czech Republic & $0.6 \%(0.0 \%-1.4 \%)$ & $40.1 \%(33.3 \%-46.9 \%)$ & $13.2 \%(9.0 \%-17.4 \%)$ \\
\hline Dominican Republic & $5.4 \%(3.5 \%-7.3 \%)$ & $29.8 \%(25.7 \%-33.9 \%)$ & $8.5 \%(6.6 \%-10.4 \%)$ \\
\hline Ecuador & $2.1 \%(1.1 \%-3.1 \%)$ & $33.3 \%(28.3 \%-38.2 \%)$ & $4.0 \%(2.9 \%-5.2 \%)$ \\
\hline Estonia & $1.0 \%(0.0 \%-2.9 \%)$ & $28.3 \%(23.5 \%-33.1 \%)$ & $8.8 \%(5.8 \%-11.7 \%)$ \\
\hline Ethiopia & $10.8 \%(7.2 \%-14.3 \%)$ & $19.3 \%(16.8 \%-21.8 \%)$ & $1.2 \%(0.2 \%-2.2 \%)$ \\
\hline Georgia & $1.3 \%(0.5 \%-2.0 \%)$ & $45.0 \%(41.2 \%-48.8 \%)$ & $5.9 \%(4.4 \%-7.4 \%)$ \\
\hline Ghana & $13.9 \%(11.1 \%-16.7 \%)$ & $12.0 \%(10.0 \%-13.9 \%)$ & $2.5 \%(1.6 \%-3.5 \%)$ \\
\hline Guatemala & $4.1 \%(2.9 \%-5.3 \%)$ & $25.8 \%(23.4 \%-28.3 \%)$ & $6.5 \%(4.9 \%-8.1 \%)$ \\
\hline Hungary & $6.8 \%(6.2 \%-7.4 \%)$ & $37.5 \%(33.2 \%-41.8 \%)$ & $11.7 \%(9.0 \%-14.5 \%)$ \\
\hline India & $28.9 \%(25.1 \%-32.7 \%)$ & $5.9 \%(4.4 \%-7.5 \%)$ & $0.8 \%(0.5 \%-1.1 \%)$ \\
\hline Kazakhstan & $0.4 \%(0.2 \%-0.6 \%)$ & $32.6 \%(28.8 \%-36.3 \%)$ & $5.9 \%(3.8 \%-81.0 \%)$ \\
\hline Kenya & $14.5 \%(11.5 \%-17.6 \%)$ & $13.3 \%(10.0 \%-16.5 \%)$ & $1.8 \%(1.0 \%-2.6 \%)$ \\
\hline Laos & $9.3 \%(7.3 \%-11.3 \%)$ & $9.1 \%(7.2 \%-11.0 \%)$ & $0.7 \%(0.3 \%-1.0 \%)$ \\
\hline Latvia & $0.5 \%(0.0 \%-1.3 \%)$ & $35.3 \%(28.3 \%-42.3 \%)$ & $9.6 \%(5.4 \%-13.9 \%)$ \\
\hline Malawi & $7.6 \%(5.6 \%-9.7 \%)$ & $23.3 \%(20.6 \%-25.9 \%)$ & $5.4 \%(4.0 \%-6.9 \%)$ \\
\hline Malaysia & $10.1 \%(7.8 \%-12.4)$ & $21.8 \%(19.4 \%-24.2 \%)$ & $8.4 \%(5.9 \%-10.9 \%)$ \\
\hline Mali & $7.5 \%(3.5 \%-11.5 \%)$ & $22.5 \%(16.2 \%-28.8 \%)$ & $5.9 \%(3.0 \%-8.8 \%)$ \\
\hline Mauritania & $11.1 \%(8.5 \%-13.8 \%)$ & $22.5 \%(17.0 \%-27.9 \%)$ & $4.6 \%(2.8 \%-6.4 \%)$ \\
\hline Mauritius & $9.6 \%(7.5 \%-11.7 \%)$ & $20.8 \%(18.4 \%-23.3 \%)$ & $4.9 \%(3.7 \%-6.1 \%)$ \\
\hline Mexico & $1.6 \%(1.3 \%-2.0 \%)$ & $40.6 \%(38.3 \%-32.8 \%)$ & $10.2 \%(9.3 \%-11.2 \%)$ \\
\hline Morocco & $6.1 \%(3.5 \%-8.7 \%)$ & $21.1 \%(17.4 \%-24.9 \%)$ & $4.0 \%(2.4 \%-5.7 \%)$ \\
\hline Myanmar & $14.6 \%(12.6 \%-16.5 \%)$ & $5.1 \%(4.2 \%-6.0 \%)$ & $0.7 \%(0.4 \%-1.0 \%)$ \\
\hline Namibia & $12.8 \%(9.9 \%-15.8 \%)$ & $18.1 \%(15.3 \%-20.9 \%)$ & $5.5 \%(4.1 \%-7.0 \%)$ \\
\hline Nepal & $16.7 \%(14.5 \%-19.0 \%)$ & $10.9 \%(8.4 \%-13.4 \%)$ & $1.4 \%(0.6 \%-2.1 \%)$ \\
\hline Pakistan & $11.0 \%(8.3 \%-13.6 \%)$ & $16.7 \%(13.1 \%-20.3 \%)$ & $4.5 \%(1.1 \%-7.9 \%)$ \\
\hline Paraguay & $3.0 \%(2.0 \%-4.0 \%)$ & $29.0 \%(26.6 \%-31.3 \%)$ & $8.8 \%(7.4 \%-10.2 \%)$ \\
\hline Philippines & $16.5 \%(15.0 \%-18.1 \%)$ & $11.2 \%(9.9 \%-12.4 \%)$ & $2.3 \%(1.7 \%-2.8 \%)$ \\
\hline Russia & $1.2 \%(0.2 \%-2.2 \%)$ & $39.9 \%(35.6 \%-44.1 \%)$ & $5.7 \%(3.6 \%-7.9 \%)$ \\
\hline Senegal & $13.0 \%(9.8 \%-16.2 \%)$ & $14.7 \%(11.5 \%-17.9 \%)$ & $2.9 \%(1.4 \%-4.4 \%)$ \\
\hline Slovakia & $0.2 \%(0.0 \%-0.5 \%)$ & $45.2 \%(37.3 \%-53.1 \%)$ & $13.0 \%(7.4 \%-18.7 \%)$ \\
\hline Slovenia & No observations & $36.2 \%(30.4 \%-42.0 \%)$ & $10.7 \%(6.7 \%-14.7 \%)$ \\
\hline South Africa & $4.9 \%(3.3 \%-6.5 \%)$ & $32.0 \%(26.8 \%-37.2 \%)$ & $19.7 \%(14.9 \%-24.4 \%)$ \\
\hline Spain & $0.9 \%(0.9 \%-1.5 \%)$ & $43.8 \%(40.0 \%-47.5 \%)$ & $10.8 \%(9.4 \%-12.3 \%)$ \\
\hline Sri Lanka & $16.2 \%(13.6 \%-18.9 \%)$ & $10.0 \%(7.4 \%-12.5 \%)$ & $2.2 \%(1.0 \%-3.5 \%)$ \\
\hline Swaziland & $1.6 \%(0.7 \%-2.6 \%)$ & $41.2 \%(35.7 \%-46.7 \%)$ & $21.4 \%(16.5 \%-26.4 \%)$ \\
\hline Tunisia & $4.8 \%(3.6 \%-6.0 \%)$ & $25.3 \%(23.0 \%-27.5 \%)$ & $4.4 \%(3.5 \%-5.4 \%)$ \\
\hline Turkey & $7.0 \%(3.2 \%-10.7 \%)$ & $32.8 \%(30.5 \%-35.0 \%)$ & $8.5 \%(7.4 \%-9.5 \%)$ \\
\hline Ukraine & $0.5 \%(0.1 \%-0.9 \%)$ & $35.0 \%(31.3 \%-38.7 \%)$ & $5.9 \%(4.4 \%-7.3 \%)$ \\
\hline United Arab Emirates & $4.7 \%(2.1 \%-7.3 \%)$ & $43.2 \%(36.5 \%-50.05 \%)$ & $13.7 \%(10.4 \%-17.1 \%)$ \\
\hline
\end{tabular}


TABLE 2: Continued.

\begin{tabular}{|c|c|c|c|}
\hline Male & Underweight & Overweight & Obese \\
\hline Country & $\%$ (95\% Confidence Intervals) & $\%$ (95\% Confidence Intervals) & $\%$ (95\% Confidence Intervals) \\
\hline Uruguay & $1.5 \%(0.7 \%-2.4 \%)$ & $34.8 \%(31.9 \%-37.7 \%)$ & $8.0 \%(6.5 \%-9.5 \%)$ \\
\hline Vietnam & $22.8 \%(18.2 \%-27.4 \%)$ & $2.7 \%(1.8 \%-3.7 \%)$ & No observations \\
\hline Zambia & $6.7 \%(4.0 \%-9.4 \%)$ & $20.6 \%(18.0 \%-23.1 \%)$ & $4.9 \%(3.0 \%-6.7 \%)$ \\
\hline Zimbabwe & $12.2 \%(10.0 \%-14.5 \%)$ & $23.6 \%(19.3 \%-28.0 \%)$ & $6.5 \%(4.5 \%-8.5 \%)$ \\
\hline Overall $^{+}$ & $7.2 \%(7.1 \%-7.4 \%)$ & $25.9 \%(25.6 \%-26.2 \%)$ & $6.5 \%(6.3 \%-6.7 \%)$ \\
\hline
\end{tabular}

${ }^{+}$Crude prevalence rates.

had a higher prevalence of underweight $(7.2 \% \mathrm{M}$ versus $6.1 \% \mathrm{~W})$, normal $\left(60.4 \%_{\mathrm{M}}\right.$ versus $\left.57.3 \% \mathrm{~W}\right)$, and overweight status $\left(25.9 \% \%_{M}\right.$ versus $\left.25.5 \% \mathrm{~W}\right)$. Tables 2 and 3 provide sexspecific prevalence figures for each country in the sample. Women had a higher prevalence of obese status $(11.1 \% \mathrm{~W}$ versus $6.5 \% \mathrm{M})$. Despite the globally higher prevalence of underweight status among men, statistical analyses showed that they were at higher risk of being underweight in five countries and at lower risk of being underweight in 15 countries. The specific listing of countries within each category is provided in Table 4 . In terms of overweight status, men were at a higher risk to be overweight in 10 countries and lower risk to be overweight in 13 countries. Men were at a higher risk to be obese in two countries and lower risk to be obese in 31 countries.

3.2.2. Income. Figure 1 provides information on the prevalence of underweight, normal, overweight, and obese status by income quintile. The prevalence of underweight status was lowest (5.8\%) and the prevalence of overweight $(27.4 \%)$ and obese status $(9.3 \%)$ was highest in the richest income quintile. In 11 countries, individuals in lower income quintiles compared to the highest income quintile were more likely underweight. Individuals in lower-income quintiles were less likely to be overweight in 34 countries and more likely to be overweight in three countries. In terms of obese status, lower income quintiles were less likely to be obese in 24 countries and more likely to be obese in two countries. In Mexico, data suggested a curvilinear association between income and being either overweight or obese. In Spain, lower income individuals were more likely to be overweight or obese than those in the richest income quintile.

3.2.3. Urbanicity. Compared to rural areas, urban areas had the lowest prevalence of underweight status (5.1\%u versus $\left.9.3 \%_{\mathrm{R}}\right)$ and the highest prevalence of overweight $\left(29.4 \%_{\mathrm{U}}\right.$ versus $\left.21.2 \%_{R}\right)$ and obesity $\left(10.6 \%_{U}\right.$ versus $\left.6.9 \%_{R}\right)$. As shown in Figure 2, Southeast Asia had the highest prevalence of underweight status in rural $(18.8 \%)$ and urban areas (14.5\%); Europe had the highest prevalence of overweight $(32.9 \%)$ and obese status $(11.9 \%)$ in rural areas, while the Americas had the highest prevalence of overweight $(34.2 \%)$ and obesity status (12.9\%) in urban areas. Within countries, residents of urban areas were at higher risk of being underweight in Brazil and at lower risk of being underweight in Laos and Sri Lanka. Residents of urban areas were at higher risk of being overweight in four countries and at lower risk in three countries. Urban residents were at higher risk of being obese in eight countries and at lower risk of being obese in three countries.

\section{Discussion}

The prevalence of underweight, overweight, and obesity varied extensively on a country-by-country basis. Underweight had a higher prevalence in Southeast Asian and Asian countries, whereas higher prevalence of overweight and obesity tended to characterize Europe and the Americas. Men tended toward a higher prevalence of overweight, normal, and underweight status while women had a generally higher prevalence of obesity. This finding was expected given studies showing that women generally have higher rates of obesity than men, although men may have higher rates of overweight status [27]. Despite the overall lower BMI distribution for men, men were at lower risk for underweight status in 15 countries compared to only five countries where women were at lower risk. Men were at higher risk of being obese in only Slovakia and Spain, although they were at lower risk in 31 countries.

Within countries, respondents belonging to households with greater income tended to be at lower risk for undernutrition and at higher risk for being overweight or obese. This inverse socioeconomic gradient in overweight and obesity in developing countries has been reported previously [28, 29]. Household increases in wealth and income in developing and transitional countries have been linked to dietary changes among higher income households. Greater wealth has tended historically to be associated with diets richer in animal fats leading to a higher prevalence of overweight and obesity in higher-income groups [10]. Despite the overall pattern found in this study, longitudinal research looking at trends over time suggests that lower SES groups in developing countries are increasingly at greater risk for overweight and obesity [3]. At gross national income per capita (GNI/c) values of roughly US\$2500, lower-income has been reported to become a risk factor for overweight and obesity rather than a protective factor [30]. In terms of year 2000 gross domestic product per capita $(\mathrm{GDP} / \mathrm{c})$ at purchasing power parity values, this study observed a cutoff at GDP/c values less than US\$8700. Below US\$8700, lower income groups were at lower risk for obesity and overweight with the exception of Chad; above US\$8700, there tended, with the 
TABLe 3: Prevalence of body mass index (BMI) classification, by sex (female) and country, WHS, 2002-2003.

\begin{tabular}{|c|c|c|c|}
\hline Female & Underweight & Overweight & Obese \\
\hline Country & $\%$ (95\% Confidence Intervals) & $\%$ (95\% Confidence Intervals) & $\%(95 \%$ Confidence Intervals) \\
\hline Bangladesh & $10.6 \%(2.2 \%-18.9)$ & $26.6 \%(14.8 \%-38.5 \%)$ & $5.9 \%(-0.1-11.9 \%)$ \\
\hline Bosnia and Herzegovina & $4.1 \%(1.2 \%-6.9 \%)$ & $28.5 \%(23.9 \%-32.2 \%)$ & $7.1 \%(5.0 \%-9.2 \%)$ \\
\hline Brazil & $5.3 \%(4.1 \%-6.4 \%)$ & $31.9 \%(29.5 \%-34.2 \%)$ & $9.6 \%(8.2 \%-11.0 \%)$ \\
\hline Burkina Faso & $7.1 \%(2.9 \%-11.3 \%)$ & $9.4 \%(7.1 \%-11.6 \%)$ & $1.4 \%(0.6 \%-2.2 \%)$ \\
\hline Chad & $6.1 \%(4.4 \%-7.7 \%)$ & $24.3 \%(21.1 \%-27.5 \%)$ & $6.5 \%(4.7 \%-8.2 \%)$ \\
\hline China & $12.7 \%(8.2 \%-17.2 \%)$ & $10.7 \%(8.7 \%-12.6 \%)$ & $1.0 \%(0.6 \%-1.5 \%)$ \\
\hline Comoros & $8.7 \%(6.3 \%-11.1 \%)$ & $22.9 \%(18.1 \%-27.6 \%)$ & $3.8 \%(2.5 \%-5.2 \%)$ \\
\hline Congo & $4.1 \%(2.3 \%-5.9 \%)$ & $19.0 \%(14.7 \%-23.2 \%)$ & $7.3 \%(3.0 \%-11.5 \%)$ \\
\hline Côte d'Ivoire & $5.0 \%(3.7 \%-6.4 \%)$ & $21.8 \%(18.0 \%-25.7 \%)$ & $5.9 \%(4.1 \%-7.7 \%)$ \\
\hline Croatia & $4.9 \%(1.4 \%-8.3 \%)$ & $27.8 \%(22.1 \%-33.4 \%)$ & $9.3 \%(7.0 \%-11.7 \%)$ \\
\hline Czech Republic & $5.4 \%(1.6 \%-9.3 \%)$ & $34.1 \%(27.7 \%-40.5 \%)$ & $10.6 \%(7.5 \%-13.7 \%)$ \\
\hline Dominican Republic & $5.6 \%(3.9 \%-7.4 \%)$ & $26.8 \%(21.3 \%-32.3 \%)$ & $14.0 \%(9.1 \%-19.0 \%)$ \\
\hline Ecuador & $2.6 \%(1.5 \%-3.6 \%)$ & $29.1 \%(25.0 \%-33.1 \%)$ & $10.2 \%(8.2 \%-12.3 \%)$ \\
\hline Estonia & $3.6 \%(1.3 \%-5.8 \%)$ & $26.8 \%(23.3 \%-30.2 \%)$ & $14.1 \%(11.6 \%-16.6 \%)$ \\
\hline Ethiopia & $15.7 \%(8.3 \%-23.2 \%)$ & $9.5 \%(5.6 \%-13.3 \%)$ & $5.2 \%(0.1 \%-10.4 \%)$ \\
\hline Georgia & $5.8 \%(4.1 \%-7.5 \%)$ & $27.3 \%(23.6 \%-31.1 \%)$ & $9.0 \%(7.4 \%-10.5 \%)$ \\
\hline Ghana & $9.1 \%(7.4 \%-10.8 \%)$ & $18.1 \%(16.0 \%-20.3 \%)$ & $7.2 \%(5.8 \%-8.7 \%)$ \\
\hline Guatemala & $3.5 \%(1.7 \%-5.4 \%)$ & $29.3 \%(26.4 \%-32.1 \%)$ & $11.2 \%(9.3 \%-13.1 \%)$ \\
\hline Hungary & $10.4 \%(7.0 \%-13.7 \%)$ & $27.8 \%(23.8 \%-31.8 \%)$ & $13.3 \%(10.8 \%-15.8 \%)$ \\
\hline India & $17.1 \%(14.8 \%-19.3 \%)$ & $9.6 \%(6.3 \%-12.9 \%)$ & $2.5 \%(1.4 \%-3.5 \%)$ \\
\hline Kazakhstan & $7.2 \%(2.9 \%-11 \%)$ & $28.3 \%(24.4 \%-32.4 \%)$ & $10.2 \%(8.1 \%-12.3 \%)$ \\
\hline Kenya & $6.0 \%(4.6 \%-7.4 \%)$ & $15.4 \%(13.2 \%-17.6 \%)$ & $7.2 \%(4.9 \%-9.5 \%)$ \\
\hline Laos & $9.0 \%(5.4 \%-12.5 \%)$ & $11.9 \%(9.3 \%-14.4 \%)$ & $1.7 \%(0.9 \%-2.4 \%)$ \\
\hline Latvia & $2.6 \%(1.0 \%-4.3 \%)$ & $25.4 \%(21.2 \%-29.5 \%)$ & $16.5 \%(12.8 \%-20.2 \%)$ \\
\hline Malawi & $7.9 \%(6.3 \%-9.5 \%)$ & $22.8 \%(20.1 \%-25.5 \%)$ & $6.1 \%(4.7 \%-7.5 \%)$ \\
\hline Malaysia & $6.4 \%(5.0 \%-7.9 \%)$ & $25.0 \%(21.4 \%-28.5 \%)$ & $9.2 \%(7.5 \%-10.8 \%)$ \\
\hline Mali & $2.0 \%(-0.8 \%-4.8 \%)$ & $33.8 \%(24.7 \%-43.0 \%)$ & $5.1 \%(-0.4 \%-10.6 \%)$ \\
\hline Mauritania & $7.1 \%(5.1 \%-9.1 \%)$ & $28.7 \%(26.1 \%-31.3 \%)$ & $12.0 \%(9.9 \%-14.1 \%)$ \\
\hline Mauritius & $9.2 \%(6.8 \%-11.6 \%)$ & $23.8 \%(19.9 \%-27.6 \%)$ & $10.1 \%(5.4 \%-14.8 \%)$ \\
\hline Mexico & $2.1 \%(1.1 \%-3.1 \%)$ & $33.1 \%(31.6 \%-34.5 \%)$ & $16.7 \%(15.7 \%-17.7 \%)$ \\
\hline Morocco & $5.7 \%(1.6 \%-9.8 \%)$ & $28.9 \%(22.6 \%-35.3 \%)$ & $15.6 \%(9.4 \%-21.7 \%)$ \\
\hline Myanmar & $13.3 \%(11.5 \%-15.1 \%)$ & $8.8 \%(7.6 \%-10.0 \%)$ & $1.1 \%(0.8 \%-1.5 \%)$ \\
\hline Namibia & $15.2 \%(11.4 \%-19.1 \%)$ & $17.8 \%(15.6 \%-20.0 \%)$ & $10.6 \%(8.9 \%-12.3 \%)$ \\
\hline Nepal & $14.2 \%(10.5 \%-18.0 \%)$ & $14.7 \%(9.9 \%-19.5 \%)$ & $2.6 \%(0.8 \%-4.3 \%)$ \\
\hline Pakistan & $8.6 \%(6.1 \%-11.1 \%)$ & $28.4 \%(22.7 \%-34.0 \%)$ & $7.2 \%(4.6 \%-9.9 \%)$ \\
\hline Paraguay & $4.8 \%(3.7 \%-5.8 \%)$ & $33.6 \%(31.2 \%-36.1 \%)$ & $10.9 \%(9.5 \%-12.3 \%)$ \\
\hline Philippines & $9.2 \%(7.9 \%-10.4 \%)$ & $12.4 \%(10.9 \%-14.0 \%)$ & $4.6 \%(2.1 \%-7.1 \%)$ \\
\hline Russia & $5.4 \%(2.5 \%-8.4 \%)$ & $27.5 \%(23.9 \%-31.0 \%)$ & $15.0 \%(11.5 \%-18.5 \%)$ \\
\hline Senegal & $9.1 \%(5.9 \%-12.3 \%)$ & $19.8 \%(15.2 \%-24.3 \%)$ & $10.3 \%(4.5 \%-16.1 \%)$ \\
\hline Slovakia & $6.7 \%(3.9 \%-9.5 \%)$ & $24.1 \%(19.8 \%-28.5 \%)$ & $14.5 \%(9.6 \%-19.4 \%)$ \\
\hline Slovenia & $5.9 \%(2.2 \%-9.5 \%)$ & $25.4 \%(20.4 \%-30.5 \%)$ & $11.3 \%(7.9 \%-14.7 \%)$ \\
\hline South Africa & $4.9 \%(3.1 \%-6.7 \%)$ & $31.9 \%(28.2 \%-35.6 \%)$ & $28.1 \%(24.5 \%-31.7 \%)$ \\
\hline Spain & $3.0 \%(1.9 \%-4.1 \%)$ & $28.0 \%(25.4 \%-30.7 \%)$ & $13.4 \%(11.2 \%-15.5 \%)$ \\
\hline Sri Lanka & $13.8 \%(10.9 \%-16.6 \%)$ & $12.5 \%(9.1 \%-15.9 \%)$ & $4.1 \%(2.7 \%-5.5 \%)$ \\
\hline Swaziland & $2.8 \%(1.4 \%-4.2 \%)$ & $34.0 \%(27.8 \%-40.2 \%)$ & $32.3 \%(26.8 \%-37.8 \%)$ \\
\hline Tunisia & $5.7 \%(2.5 \%-8.8 \%)$ & $28.0 \%(24.7 \%-31.4 \%)$ & $10.0 \%(8.5 \%-11.6 \%)$ \\
\hline Turkey & $5.5 \%(4.3 \%-6.8 \%)$ & $30.6 \%(28.3 \%-32.8 \%)$ & $15.0 \%(12.9 \%-17.1 \%)$ \\
\hline Ukraine & $6.0 \%(4.1 \%-7.9 \%)$ & $25.9 \%(22.4 \%-29.4 \%)$ & $12.6 \%(10.5 \%-14.7 \%)$ \\
\hline United Arab Emirates & $8.2 \%(4.7 \%-11.8 \%)$ & $38.9 \%(32.0 \%-45.7 \%)$ & $16.7 \%(12.2 \%-21.1 \%)$ \\
\hline
\end{tabular}


Table 3: Continued.

\begin{tabular}{lccc}
\hline Female & Underweight & Overweight & $\begin{array}{c}\text { Obese } \\
\text { Country }\end{array}$ \\
\hline Uruguay & $4.3 \%(2.7 \%-5.8 \%)$ & $25.0 \%(22.3 \%-27.8 \%)$ & $12.2 \%(10.2 \%-14.3 \%)$ \\
Vietnam & $12.1 \%(10.0 \%-14.2 \%)$ & $7.2 \%(3.1 \%-11.2 \%)$ & $0.6 \%(0.1 \%-1.1 \%)$ \\
Zambia & $11.1 \%(7.4 \%-14.7 \%)$ & $16.8 \%(14.0 \%-19.6 \%)$ & $7.1 \%(5.3 \%-8.8 \%)$ \\
Zimbabwe & $5.0 \%(1.8 \%-8.3 \%)$ & $28.5 \%(24.1 \%-32.9 \%)$ & $11.2 \%(8.8 \%-13.5 \%)$ \\
Overall $^{+}$ & $6.1 \%(6.0 \%-6.3 \%)$ & $25.5 \%(25.2 \%-25.8 \%)$ & $11.1 \%(10.9 \%-11.3 \%)$ \\
\hline
\end{tabular}

${ }^{+}$Crude prevalence rates.

TABle 4: Summary results for countries with adjusted relative risk ratios (RRRs) and 95\% Confidence Interval (CI) with $P<.05$ from multinomial multivariable models regressing BMI classification on sex, age, income, and urbanicity, WHS, 2002-2003.

\begin{tabular}{|c|c|c|c|}
\hline & Underweight & Overweight & Obese \\
\hline \multicolumn{4}{|l|}{ (1) Sex } \\
\hline $\begin{array}{l}\text { Men at higher risk RRR }> \\
1.00, P<.05\end{array}$ & $\begin{array}{l}\text { (5) India, Kenya, Malaysia, Sri } \\
\text { Lanka, Zimbabwe }\end{array}$ & $\begin{array}{l}\text { (10) Croatia, Czech Republic, } \\
\text { Dominican Republic, Ecuador, } \\
\text { Georgia, Mexico, Paraguay, } \\
\text { Slovakia, Spain, Uruguay }\end{array}$ & (2) Slovakia, Spain \\
\hline $\begin{array}{l}\text { Men at lower risk } \mathrm{RRR}<1.00 \text {, } \\
P<.05\end{array}$ & $\begin{array}{l}\text { (15) Brazil, Comoros, Côte } \\
\text { d'Ivoire, Czech Republic, } \\
\text { Dominican Republic, Estonia, } \\
\text { Georgia, Hungary, Kazakhstan, } \\
\text { Paraguay, Russian Federation, } \\
\text { Slovakia, Turkey, Ukraine, } \\
\text { Uruguay }\end{array}$ & $\begin{array}{l}\text { (13) Comoros, Ghana, } \\
\text { Guatemala, India, Kenya, Laos, } \\
\text { Mauritania, Morocco, Myanmar, } \\
\text { Pakistan, Senegal, Tunisia, } \\
\text { Zimbabwe }\end{array}$ & $\begin{array}{l}\text { (31) Bosnia and Herzegovina, } \\
\text { Brazil, Burkina Faso, Comoros, } \\
\text { Côte d'Ivoire, Estonia, Ghana, } \\
\text { Guatemala, India, Kazakhstan, } \\
\text { Kenya, Latvia, Malaysia, } \\
\text { Mauritania, Mauritius, Mexico, } \\
\text { Morocco, Myanmar, Namibia, } \\
\text { Nepal, Philippines, Russian } \\
\text { Federation, Senegal, South } \\
\text { Africa, Sri Lanka, Swaziland, } \\
\text { Tunisia, Turkey, Ukraine, } \\
\text { Zambia, Zimbabwe }\end{array}$ \\
\hline
\end{tabular}

(2) Income

(11) Brazil, Chad, India, Kenya,

Lower quintiles at higher risk Malaysia, Nepal, Paraguay, South RRR $>1.00, P<.05 \quad$ Africa, Sri Lanka, Vietnam, Zambia

Lower quintiles at lower risk RRR $<1.00, P<.05$
(3) Chad, Mexico, Spain

(2) Mexico, Spain

(34) Bosnia and Herzegovina, Brazil, China, Comoros, Congo, Côte d'Ivoire, Dominican Republic, Ecuador, Estonia, Georgia, Ghana, Guatemala, India, Kazakhstan, Kenya, Laos, Malawi, Malaysia, Mexico, Morocco, Myanmar, Namibia, Nepal, Pakistan, Paraguay, Philippines, Russian Federation, Senegal, Sri Lanka, Tunisia, Ukraine, Vietnam, Zambia, Zimbabwe

\section{(3) Urbanicity}

Urban areas at higher risk RRR $>1.00, P<.05$

(1) Brazil

Urban areas at lower risk RRR $<1.00, P<.05$
(2) Laos, Sri Lanka
(4) Brazil, Ghana, India, Myanmar

(3) Latvia, Slovakia, Spain
(24) Brazil, Congo, Dominican Republic, Georgia, Ghana, Guatemala, India, Kazakhstan, Kenya, Laos, Malawi, Mexico, Myanmar, Namibia, Nepal, Pakistan, Paraguay, Philippines, Russian Federation, Tunisia, Ukraine, Vietnam, Zambia, Zimbabwe

(8) Bosnia and Herzegovina, Burkina Faso, Dominican Republic, Ghana, India, Myanmar, Tunisia, Zimbabwe

(3) Malaysia, Nepal, Slovakia 


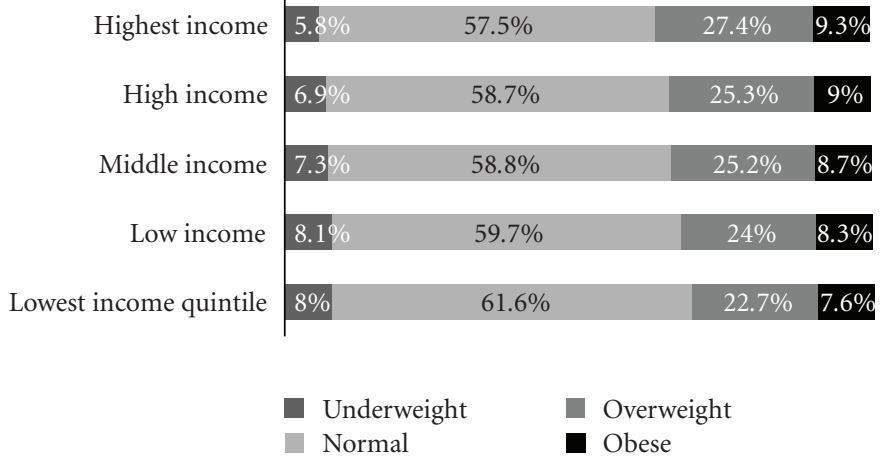

Figure 1: Prevalence of BMI classification by income quintile, WHS, 2002-2003.

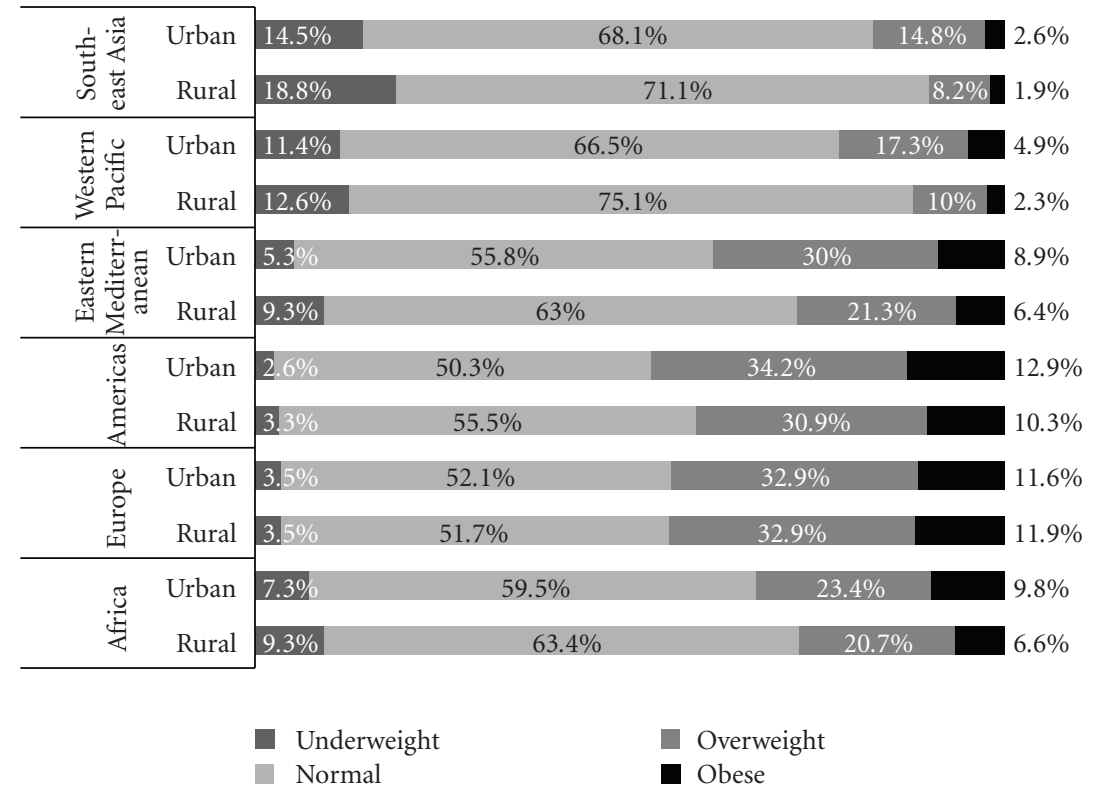

FIgURE 2: Prevalence of BMI classification by WHO region and urbanicity, WHS, 2002-2003.

exception of Spain, to be no difference between income groups. In Mexico, the lowest quintile had a lower risk for overweight and obesity compared to the highest quintile, but two middle income quintiles were at a higher risk of overweight and obesity than the richest quintile. Residents of lower income households in Spain (the country with the highest GDP/c in this sample) had a higher risk of overweight or obesity.

Rapid urbanization often results in complex societal changes that can have beneficial and adverse impacts on population health [31]. Urbanization has been identified as a key factor fueling the nutrition transition [32, 33]. Urbanization is accompanied by technological changes that influence activity patterns and levels, increased access to modern media, and greater access and exposure to foods richer in fats, caloric sweeteners, and edible oils across all seasons of the year [34]. Urban areas were found in this study to have the lowest prevalence of underweight status and the highest prevalence of overweight and obesity.
Comparisons of urban and rural differences within world regions showed urbanicity important in all regions except Europe. However, as a risk factor associated with BMI status, the results were mixed. Countries as diverse as Brazil, India, Ghana, and Myanmar showed residents of urban areas with a higher risk of being underweight, or overweight or obese. On the other hand, countries such as Slovakia, Malaysia, and Spain showed residents of urban areas with a lower risk of being overweight or obese. Adjustment for age and income in the regression analyses may have reduced the association of urbanicity with overweight and obesity since urban areas tend to have younger age strata and wealthier households compared to their rural counterparts [35].

Direct comparability between this study's malnutrition prevalence estimates and those of other studies is difficult due to differences in sampling design, instruments, data collection methods (e.g., self-report versus directly measured), and the time period in which the data were collected. 
For these reasons, there may be variability in the extent to which this study's prevalence estimates compare to previous reports. For example, this study found that $11.7 \%$ of Chinese adults reported either overweight or obese; $18.9 \%$ of Chinese adults have been previously reported as overweight or obese $[20,36]$; 36.6\% of Brazilian adults were found overweight or obese in this study, whereas Brazilian ministries reported $40.6 \%$ of its residents overweight or obese [20]. This study found $47.3 \%$ of Spanish adults overweight or obese and $2.1 \%$ underweight compared to $49 \%$ of adults overweight or obese and $2.7 \%$ underweight previously reported [20,37]. In South Africa, 23.2\% of respondents were obese and 5.3\% underweight in this study, whereas in 1999 the South African Department of Health reported $21.6 \%$ of adults obese and $8.6 \%$ underweight $[20,38]$.

One limitation of the present study is the use of selfreported measures of height and weight instead of direct measures to estimate the prevalence of overweight and obesity status. Social desirability may play a role in the amount of bias that self reports introduce into population estimates of BMI [13]. For example, research in the United States and Canada has shown a tendency of overreporting of height and underreporting of weight [13]. Young collegeeducated students in Thailand were found to underreport weight and overreport height in ways similar to persons in developed countries [39]. Correction estimates available from such studies may not however have cross-cultural validity since societies and groups may not share the same norms of what is socially desirable. Yet, research has shown self-reported height and weight to be equally correlated to fasting blood glucose, high-density lipoprotein-cholesterol, and systolic blood pressure as direct measures [14], and related longitudinally to mortality [15]. Given the lower survey costs, higher response rates, and its relevance for epidemiological studies, use of self-reported height and weight to estimate the prevalence of obesity, overweight, and underweight will continue to have a place in current research on global malnutrition.

Underweight, overweight, and obesity are among the leading risk factors in the global burden of disease. Knowledge of the socio-economic factors associated with overweight and obesity and how these factors are embedded in specific national contexts can contribute to the development of policies that target these factors. This is important since along with fruit and vegetable consumption, smoking, and physical activity, overweight and obesity constitute one of the major risk factors for chronic diseases. Yet, recognition of overweight and obesity as a global pandemic and public health problem for all countries has been slow in coming [40]. Establishing international and regional policies that recognize national variability in the factors associated with this global pandemic may contribute to reducing global inequalities in underweight and obesity.

\section{Conflict of Interest}

The authors declare no conflict of interest.

\section{Acknowledgments}

At the time of this research, S. Moore was supported through a New Investigator Award from the CIHR-Institute of Aging. J. Hall was supported through a Masters fellowship from the Canadian Institutes of Health Research (CIHR). J. Lynch is a Senior Professorial Research Fellow supported by the National Health and Medical Research Council of Australia. This paper uses data from the WHO World Health Surveys. Research on the WHS was made possible by a research grant from the CIHR-Institute of Population Health (WHOAnalysis of the World Health Survey, 162602).

\section{References}

[1] World Health Organization, "Obesity and Overweight," July 2009, http://www.who.int/mediacentre/factsheets/fs311/ en/index.html.

[2] G. Kennedy, G. Nantel, and P. Shetty, "Assessment of the double burden of malnutrition in six case study countries," 2006, 84. June 2009, ftp://ftp.fao.org/docrep/fao/009/ a0442e/a0442e00.pdf.

[3] B. M. Popkin, "Global changes in diet and activity patterns as drivers of the nutrition transition," Nestle Nutrition Workshop Series: Pediatric Program, vol. 63, pp. 1-14, 2009.

[4] B.M. Popkin, "The nutrition transition: an overview of world patterns of change," Nutrition Reviews, vol. 62, no. 7, pp. S140S143, 2004.

[5] A. C. Bell, K. Ge, and B. M. Popkin, "Weight gain and its predictors in Chinese adults," International Journal of Obesity, vol. 25, no. 7, pp. 1079-1086, 2001.

[6] World Health Organization, "WHO Child Growth Standards: Backgrounder 4," June 2009, http://www.who.int/childgrowth/4_double_burden.pdf.

[7] U. E. Schaible and S. H. E. Kaufmann, "Malnutrition and infection: complex mechanisms and global impacts," PLoS Medicine, vol. 4, no. 5, article e115, 2007.

[8] R. E. Black, L. H. Allen, Z. A. Bhutta, et al., "Maternal and child undernutrition: global and regional exposures and health consequences," The Lancet, vol. 371, no. 9608, pp. 243260, 2008.

[9] B. M. Popkin, "Understanding the nutrition transition," Urbanisation and Health Newsletter, no. 30, pp. 3-19, 1996.

[10] A. Drewnowski and B. M. Popkin, "The nutrition transition: new trends in the global diet," Nutrition Reviews, vol. 55, no. 2, pp. 31-43, 1997.

[11] C. M. Doak, L. S. Adair, M. Bentley, C. Monteiro, and B. M. Popkin, "The dual burden household and the nutrition transition paradox," International Journal of Obesity, vol. 29, no. 1, pp. 129-136, 2005.

[12] C. Doak, "Large-scale interventions and programmes addressing nutrition-related chronic diseases and obesity: examples from 14 countries," Public Health Nutrition, vol. 5, no. 1, pp. 275-277, 2002.

[13] S. C. Gorber, M. Tremblay, D. Moher, and B. Gorber, "A comparison of direct vs. self-report measures for assessing height, weight and body mass index: a systematic review," Obesity Reviews, vol. 8, no. 4, pp. 307-326, 2007.

[14] M. A. McAdams, R. M. van Dam, and F. B. Hu, "Comparison of self-reported and measured BMI as correlates of disease markers in U.S. adults," Obesity, vol. 15, no. 1, pp. 188-196, 2007. 
[15] J. M. Dorn, E. F. Schisterman, W. Winkelstein Jr., and M. Trevisan, "Body mass index and mortality in a general population sample of men and women: the Buffalo health study," American Journal of Epidemiology, vol. 146, no. 11, pp. 919-931, 1997.

[16] E. A. Spencer, P. N. Appleby, G. K. Davey, and T. J. Key, "Validity of self-reported height and weight in 4808 EPICOxford participants," Public Health Nutrition, vol. 5, no. 4, pp. 561-565, 2002.

[17] World Health Organization, "World Health Survey," June 2009, http://www.who.int/healthinfo/survey/en/index.html.

[18] J. N. Hall, S. Moore, S. B. Harper, and J. W. Lynch, "Global variability in fruit and vegetable consumption," American Journal of Preventive Medicine, vol. 36, no. 5, pp. 402-409, 2009.

[19] T. B. Üstün, S. Chatterji, A. Mechbal, and C. J. L. Murray, "WHS collaborating groups. The world health surveys," in Health Systems Performance Assessment, C. J. L. Murray and D. B. Evans, Eds., World Health Organization, Geneva, Switzerland, 2003.

[20] World Health Organization, "Global Database on Body Mass Index: BMI Classification,” June 2009, http://apps.who.int/ bmi/index.jsp?introPage $=$ intro_3.html.

[21] C. Barba, T. Cavalli-Sforza, J. Cutter, et al., "Appropriate bodymass index for Asian populations and its implications for policy and intervention strategies," Lancet, vol. 363, no. 9403, pp. 157-163, 2004.

[22] B. Ferguson, A. Tandon, E. Gakidou, and C. Murray, "Estimating permanent income using indicator variables," in Health Systems Performance Assessment: Debates, Methods, and Empiricism, C. Murray and D. Evans, Eds., WHO, Geneva, Switzerland, 2003.

[23] S. Chatterji, P. Kowal, C. Mathers, et al., "The health of aging populations in China and India," Health Affairs, vol. 27, no. 4, pp. 1052-1063, 2008.

[24] D. Filmer and L. H. Pritchett, "Estimating wealth effects without expenditure data-or tears: an application to educational enrollments in states of India," Demography, vol. 38, no. 1, pp. 115-132, 2001.

[25] World Health Organization, "WHO_its people and offices," June 2009, http://www.who.int/about/structure/en/index .html.

[26] O. Ahmad, C. Boschi-Pinto, A. Lopez, C. Murray, R. Lozano, and M. Inoue, "Age Standardization of Rates: A New WHO Standard," June 2009, http://www.who.int/healthinfo/paper31.pdf.

[27] World Health Organization, "Obesity: preventing and managing the global epidemic," Tech. Rep. 894, World Health Organization, 2000.

[28] B. M. Popkin, "The nutrition transition and obesity in the developing world," Journal of Nutrition, vol. 131, no. 3, pp. 871S-873S, 2001.

[29] B. M. Popkin, "The nutrition transition in low-income countries: an emerging crisis," Nutrition Reviews, vol. 52, no. 9, pp. 285-298, 1994.

[30] B. M. Popkin and P. Gordon-Larsen, "The nutrition transition: worldwide obesity dynamics and their determinants," International Journal of Obesity, vol. 28, supplement 3, pp. S2S9, 2004.

[31] D. Yach, C. Mathews, and E. Buch, "Urbanisation and health: methodological difficulties in undertaking epidemiological research in developing countries," Social Science and Medicine, vol. 31, no. 4, pp. 507-514, 1990.
[32] K. L. Monda, P. Gordon-Larsen, J. Stevens, and B. M. Popkin, "China's transition: the effect of rapid urbanization on adult occupational physical activity," Social Science and Medicine, vol. 64, no. 4, pp. 858-870, 2007.

[33] B. M. Popkin, "The shift in stages of the nutrition transition in the developing world differs from past experiences!," Public Health Nutrition, vol. 5, no. 1, pp. 205-214, 2002.

[34] B. M. Popkin, "Global nutrition dynamics: the world is shifting rapidly toward a diet linked with noncommunicable diseases," American Journal of Clinical Nutrition, vol. 84, no. 2, pp. 289-298, 2006.

[35] R. W. Kimokoti and D. H. Hamer, "Nutrition, health, and aging in sub-Saharan Africa," Nutrition Reviews, vol. 66, no. 11, pp. 611-623, 2008.

[36] J. C. N. Chan, V. Malik, W. Jia, et al., "Diabetes in Asia: epidemiology, risk factors, and pathophysiology," Journal of the American Medical Association, vol. 301, no. 20, pp. 21292140, 2009.

[37] A. García-Álvarez, L. Serra-Majem, L. Ribas-Barba, et al., "Obesity and overweight trends in Catalonia, Spain (19922003): gender and socio-economic determinants," Public Health Nutrition, vol. 10, no. 11, pp. 1368-1378, 2007.

[38] South Africa, Medical Research Council. South Africa Demographic Health Survey, 1998.

[39] L. L. Y. Lim, S.-A. Seubsman, and A. Sleigh, "Validity of self-reported weight, height, and body mass index among university students in Thailand: implications for population studies of obesity in developing countries," Population Health Metrics, vol. 7, p. 15, 2009.

[40] B. Popkin, The World is Fat, Avery, New York, NY, USA, 2009. 


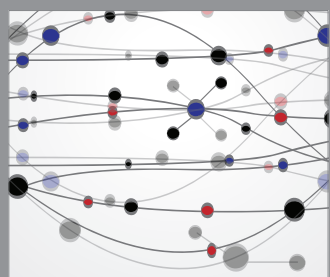

The Scientific World Journal
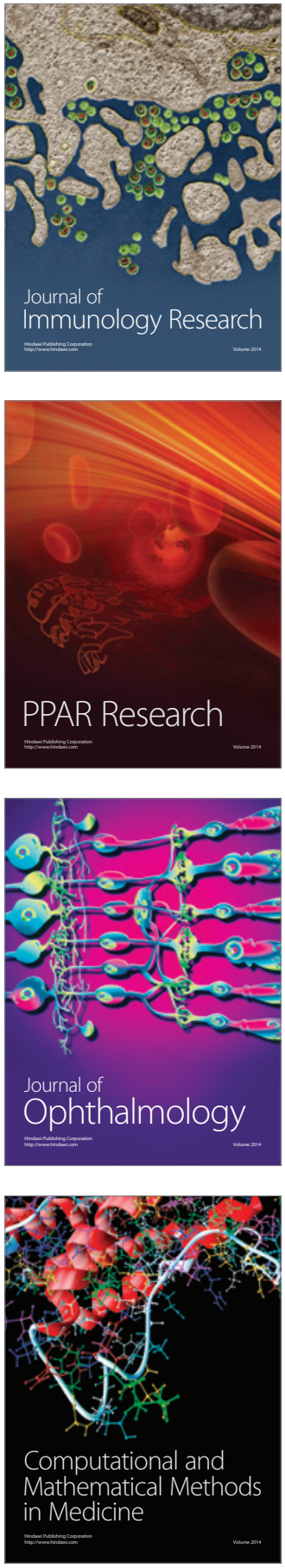

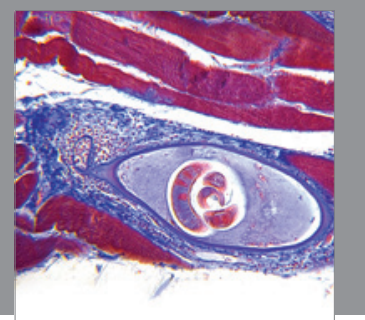

Gastroenterology

Research and Practice
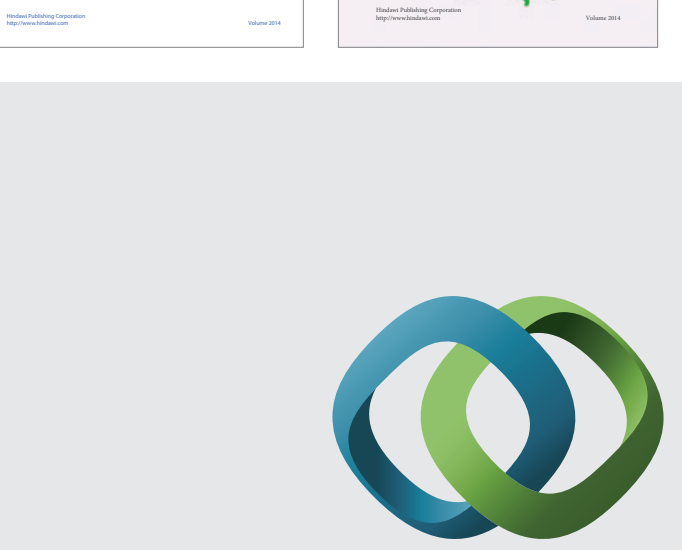

\section{Hindawi}

Submit your manuscripts at

http://www.hindawi.com
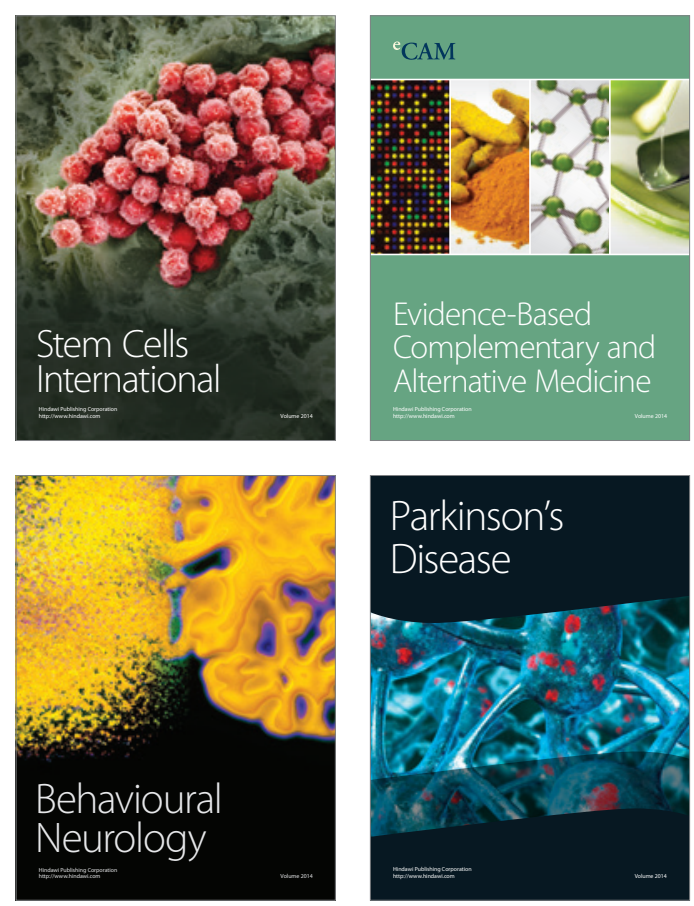

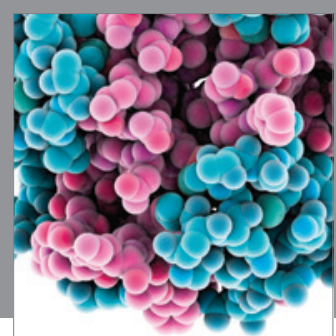

Journal of
Diabetes Research

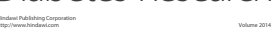

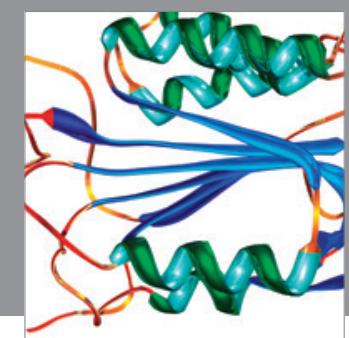

Disease Markers
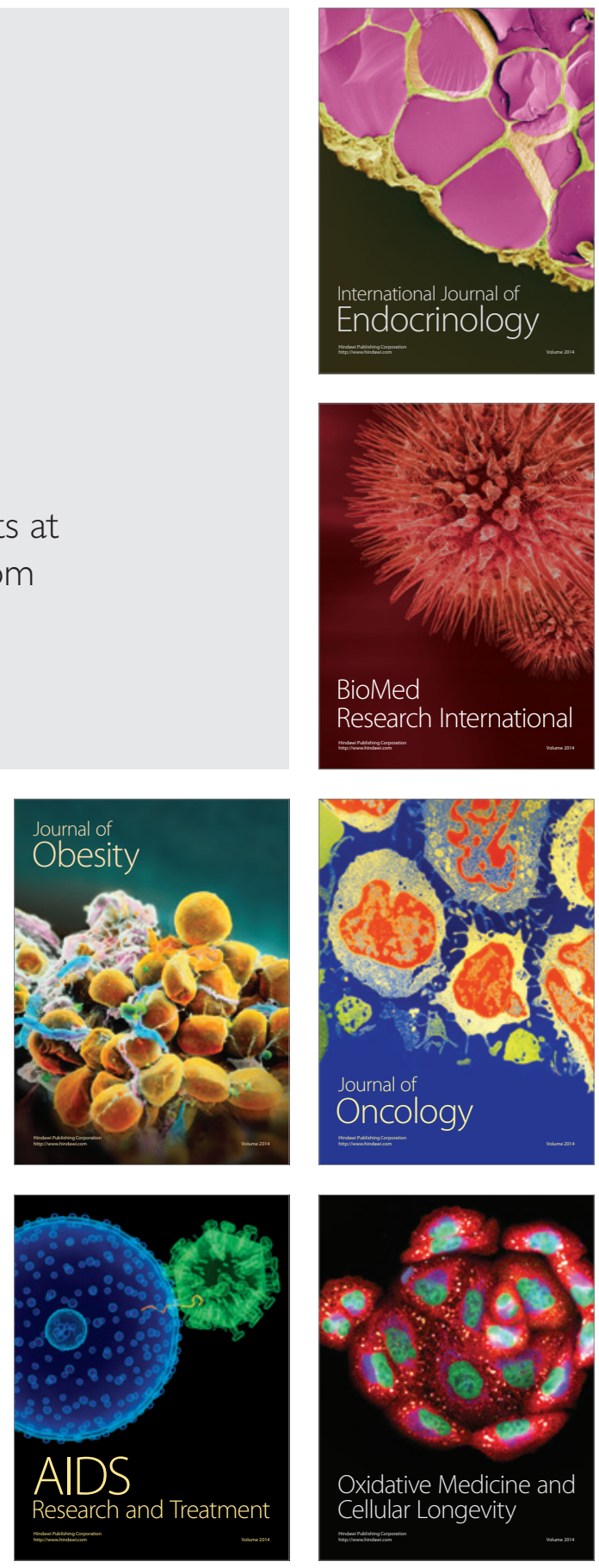